\title{
POROUS MAGNESIUM ALLOYS PREPARED BY POWDER METALLURGY
}

\author{
POROZNE MAGNEZIJEVE ZLITINE, IZDELANE S POMOČJO \\ METALURGIJE PRAHOV
}

\author{
Pavel Salvetr, Pavel Novák, Dalibor Vojtěch \\ University of Chemistry and Technology, Department of Metals and Corrosion Engineering, Technicka 5, 16628 Prague 6, Czech Republic \\ psalvetr@seznam.cz
}

Prejem rokopisa - received: 2015-07-14; sprejem za objavo - accepted for publication: 2015-10-30

doi:10.17222/mit.2015.226

\begin{abstract}
This paper deals with the development of porous magnesium alloys that can be used in medicine for bone fixations and implants. The individual components of the alloys were chosen so that the biodegradability of the material is maintained. The advantage of these magnesium materials should be an ability to decompose after some time. This should reduce the number of surgeries and consequently increase the comfort of patients. All the samples were prepared using the method of powder metallurgy. The influence of particular alloying elements - aluminium, zinc, yttrium - on the structure of the alloys was explored, with changes being seen in the area of the fraction of pores, the size and the shapes of the pores, according to the alloying elements and the prolongation of the time of sintering the powders. By altering the chemical composition and the time of sintering the demanded porosity was not achieved, and that is the reason why a pore-forming agent (ammonium carbonate) was added. It was removed by thermal decomposition before the powder's sintering. By adding ammonium carbonate we managed to increase the porosity and at the same time we obtained more pores (in equivalent diameter 200-400 $\mu \mathrm{m}$ ). The mechanical properties of the samples were tested in compression. In the samples without the pore-forming agent the values of the ultimate strength were larger than the values of natural bones. After adding the pore-forming agent the ultimate strength and modulus elasticity were reduced.
\end{abstract}

Keywords: magnesium alloys, powder metallurgy, porosity, biomaterial

Članek obravnava razvoj poroznih magnezijevih zlitin, ki bi lahko bile uporabne v medicini za utrjevanje kosti in vsadke. Posamezne komponente zlitin so bile izbrane tako, da je ostal material biološko razgradljiv. Prednost teh magnezijevih materialov naj bi bila zmožnost, da se s časom razgradi. To naj bi zmanjšalo število operacij in s tem povečalo ugodje pacientov. Vsi vzorci so bili pripravljeni po postoku metalurgije prahov. Preiskovan je bil vpliv posameznih legirnih elementov (aluminij, cink, itrij) na mikrostrukturo zlitin. Spremembe so bile opažene pri deležu por, velikosti in obliki por glede na legirni element in podališanje časa sintranja prahov. S spreminjanjem kemijske sestave in časa sintranja zahtevana poroznost ni bila dosežena in to je tudi razlog, zakaj je bilo dodano sredstvo za nastajanje por (amonijev karbonat). To sredstvo je bilo odstranjeno s toplotnim razpadom pred sintranjem prahu. $Z$ dodatkom amonijevega karbonata nam je uspelo povečati poroznost in istočasno smo dobili več por ekvivalentnega premera $200-400 \mu \mathrm{m}$. Mehanske lastnosti vzorcev so bile preizkušene s stiskanjem. Vzorci brez sredstva za nastajanje por so dosegli vrednosti porušne trdnosti večje od vrednosti pri naravnih kosteh. Po dodajanju sredstva za nastanek por sta se porušna trdnost in modul elastičnosti zmanjšala.

Ključne besede: magnezijeve zlitine, metalurgija prahov, poroznost, biomaterial

\section{INTRODUCTION}

Magnesium and its alloys have an import role among structural materials. They exceed other materials, especially with their low density. Magnesium is used mainly in the construction of vehicles and the aerospace industry, where it is used in mechanically less-strained components. These special applications include, for example, steering wheels, dashboards, seats and gearboxes. ${ }^{1}$ In the future, magnesium is also proposed to be a material able to store hydrogen. ${ }^{2}$

Nowadays, magnesium alloys are a subject of intensive research and development for applications in medicine as an osteosynthetic material. These materials have the ability to biodegrade, which means to decompose and be absorbed into a human body. The main advantages of these kinds of implants would be reducing the number of surgeries. The so far used biomaterials are based on bio-inert (non-reactive and corrosion-resistant alloys). The human body may have a problem with accepting these materials. This group comprises stainless steel, titanium and cobalt alloys. ${ }^{3}$ Biodegradable materials must fulfil many requirements, i.e., they must not release toxic doses of metallic ions and both the products of the corrosion reactions and the original biomaterial must not cause any allergic reaction of the organism. Therefore, the appropriate corrosion rates should be reached. The implant must not decompose too early. For example, a screw fixation of broken bones should work for 12-16 weeks, as a minimum. During this time the implant must keep its mechanical properties, which should be similar to the mechanical properties of natural bones. This requirement is met by magnesium and its alloys quite well, as you can see in Table 1., ${ }^{4,5,7-10}$ Zinc alloys are investigated as competitive materials for biodegradable implants. ${ }^{6}$ 
Table 1: Mechanical properties of porous biomaterials

Tabela 1: Mehanske lastnosti poroznih biomaterialov

\begin{tabular}{|c|c|c|c|c|c|}
\hline Material & $\begin{array}{c}\text { Porosity } \\
(x / \%)\end{array}$ & $\begin{array}{c}\text { Pore } \\
\text { size } \\
(\mu \mathrm{m})\end{array}$ & $\begin{array}{c}\text { Compressive } \\
\text { strength } \\
(\mathrm{MPa})\end{array}$ & $\begin{array}{c}\text { Modulus } \\
(\mathrm{GPa})\end{array}$ & $\begin{array}{c}\text { Refe- } \\
\text { rence }\end{array}$ \\
\hline Porous Mg & $29-31$ & $250-500$ & $20-70$ & - & 7 \\
\hline Porous Mg & $36-55$ & $200-400$ & $15-31$ & $4-18$ & 8 \\
\hline Porous Mg & $35-55$ & $100-400$ & $12-17$ & $1-2$ & 9 \\
\hline Porous Ti & 78 & $200-500$ & 35 & 5 & 10 \\
\hline Porous HA & $50-77$ & $200-400$ & $1-17$ & $0.1-7$ & 8 \\
\hline Natural bone & - & - & $2-180$ & $0.1-20$ & 8 \\
\hline
\end{tabular}

Magnesium alloys mostly have better mechanical properties than pure magnesium. Corrosion resistance is increased by aluminium, zinc and rare-earth metals, but alloying elements such as iron, nickel and copper make it worse. All alloying elements in biodegradable materials must maintain the biocompatibility of the alloy. The improvement of the mechanical properties happens especially by precipitation hardening or by strengthening of a solid solution. An element that can be used is zinc, which naturally occurs in body tissue. The results of biochemical and histological investigations show that the degradation of the $\mathrm{Mg}-\mathrm{Zn}$ alloy should not harm the organism. ${ }^{5}$ The maximum solubility of zinc in magnesium is $6.2 \%$ of mass fractions, and it improves the corrosion resistance and mechanical properties. The influence of aluminium on magnesium alloys is similar: it increases the strength and corrosion resistance. In a magnesium solid solution there is dissolved a maximum of $12.7 \%$ of mass fractions of aluminium. Magnesium alloys with aluminium are heat treatable to form the $\mathrm{Mg}_{17} \mathrm{Al}_{12}$ phase. Alloying with aluminium causes microporosity and according to some studies it can cause Alzheimer's disease. Other alloying elements that influence the mechanical corrosion properties in a positive way are rare-earth metals - the lanthanides, yttrium and scandium. To magnesium alloys they are usually added in relatively small amounts, where one or two elements are dominant and the rest is added only in a small amount. The rare-earth metals can be divided into a group with better solubility (Y, Gd, Tb, Dy, Ho, Er, Tm, $\mathrm{Yb}, \mathrm{Lu})$ and another group with limited solubility. Together with magnesium they create a eutectic system with limited solubility. Intermetallic phases $\left(\mathrm{Mg}_{2} \mathrm{Y}\right.$, $\mathrm{Mg}_{24} \mathrm{Y}_{5}$ ) limit the movement of dislocations and increase the ultimate tensile strength. ${ }^{11}$ Lanthanum and cerium could be added in a limited amount according to a biological test. ${ }^{12}$ Calcium and zirconium also have a positive influence on the mechanical properties. Zirconium refines the structure, while calcium hardens the magnesium-based solid solution and forms the $\mathrm{Mg}_{2} \mathrm{Ca}$ phase. Calcium is the main component of bones and in combination with magnesium it improves their healing. ${ }^{13,14}$

To ensure the osseointegration of the implant and the consequent substitution of the implant by the bone, the presence of pores with an average of 150-200 $\mu \mathrm{m}$ as a minimum is important. ${ }^{15}$ The porous structure can be produced with various processes. For sample preparation by powder metallurgy a pore.-forming agent (carbamide, ammonium bicarbonate) is added, which is removed by thermal decomposition. ${ }^{8} 16$ With this process, pores with a random distribution and size are formed. Regular ordering of the pores is achieved by low-pressure casting of the magnesium alloy into a $\mathrm{NaCl}$ template. ${ }^{17}$ This paper aims to prove the possibility of preparing porous magnesium alloys by sintering from elemental metallic powders with the addition of a pore-forming agent.

\section{EXPERIMENTAL PART}

All the samples were prepared by the method of powder metallurgy from $\mathrm{Mg}, \mathrm{Zn}$, and Y powders. The powders were blended manually and uniaxially pressed at a pressure of $530 \mathrm{MPa}$ to form cylindrical green compacts. The samples were sintered in a tubular furnace under an argon atmosphere. The sintering temperature was chosen according to the phase diagrams of the individual alloys (MgZn5: $575^{\circ} \mathrm{C}, \mathrm{MgZn10:} 405^{\circ} \mathrm{C}, \mathrm{MgY5}$ : $600{ }^{\circ} \mathrm{C}$ ). The duration of the sintering was $2 \mathrm{~h}$. For the $\mathrm{MgZn}_{5}$ and $\mathrm{MgZn}_{0}$ samples, the sintering was prolonged up to $4 \mathrm{~h}$ or $24 \mathrm{~h}$ in order to observe the influence of the sintering time on the porosity and mechanical properties. The pore-forming agent $\left(\mathrm{NH}_{4}\right)_{2} \mathrm{CO}_{3}$, which was used in some samples, was removed before sintering by thermal decomposition. The decomposition was carried out at $230{ }^{\circ} \mathrm{C}$ for $1 \mathrm{~h}$ and the products of the decomposition were drained by a flow of argon. Subsequent sintering was conducted at the same temperature as for the samples without the addition of the pore-forming agent for $4 \mathrm{~h}$.

To determine the porosity and to observe the microstructure, metallographic samples were prepared. The samples were mounted into methacrylate resin, ground by sandpapers P180-P4000 (abrasive elements $\mathrm{SiC}$ and $\mathrm{Al}_{2} \mathrm{O}_{3}$ ), polished by a water-based suspension of $\mathrm{Al}_{2} \mathrm{O}_{3}$ (Topol 2) or diamond paste D2. The microstructure of the samples was revealed by etching in Nital $(2 \mathrm{~mL}$ $\mathrm{HNO}_{3}+98 \mathrm{~mL}$ ethanol).

The microstructure was observed with an optical metallographic microscope (Olympus PME3) and documented by AxioVision image-processing software. A more detailed observation and chemical microanalysis were performed with a TESCAN VEGA 3 LMU scanning electron microscope equipped with an OXFORD Instruments INCA 350 EDS analyser.

Macrographs for the measurement of porosity were acquired with a Carl Zeiss Neophot 2 optical metallographic microscope. The porosity was evaluated with Lucia 4.8 image-analysis software as the area fraction of pores in the cross-section.

The mechanical properties of the samples were tested in compression at room temperature. The ultimate compressive strength (UCS) and modulus of elasticity E were determined from the stress-strain curves. The measure- 
ments of the mechanical properties were performed using a LabTest 5.250SP1-VM universal testing machine.

\section{RESULTS AND DISCUSSION}

In the first part of the work, the alloys were prepared by sintering mixtures of the corresponding elemental powders without the addition of the pore-forming agent. The purpose of this step was to find an alloy that can be produced using this simple production route.

\subsection{MgZn}

In the case of the $\mathrm{Mg}-\mathrm{Zn}$ alloy, the influence of the sintering duration and the amount of zinc on the structure and porosity of the samples were observed. A longer duration of sintering did not cause any changes to the microstructure of the MgZn5 alloy. The effect of a longer sintering time is a decreasing number of pores with an equivalent diameter of about $30 \mu \mathrm{m}$ and, consequently, to a better-quality sintering of the powder. However, the decrease of the fractional area of the pores is not reached in a sample sintered for $24 \mathrm{~h}$. The microstructure of the alloy $\mathrm{MgZn} 5$ (Figure 1) consists of a solid solution of $\mathrm{Mg}-\mathrm{Zn}$ with a zinc content of $4 \%$ of the mass fractions, whose grain boundaries are decorated by the intermetallic phase. This phase arises only in a thin layer and therefore its chemical composition was not determined by chemical microanalysis.

Increasing the content of zinc in the alloy up to $10 \%$ of mass fractions $(\mathrm{MgZn} 10)$ led to an increasing number of pores with a equivalent diameter up to $100 \mu \mathrm{m}$, but the overall porosity decreased. Prolongation of the sintering duration from 2 to $4 \mathrm{~h}$ slightly decreased the porosity. The porosity of the alloys is written in Table 2 . In the structure of the sample MgZn10 there are two phases: a $\mathrm{Mg}-\mathrm{Zn}$ solid solution with a zinc content of $8.6 \%$ of

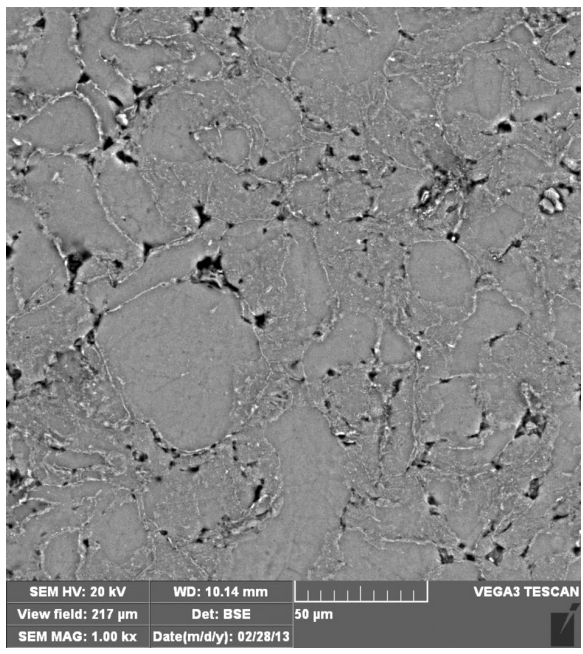

Figure 1: Microstructure of MgZn5 alloy

Slika 1: Mikrostruktura zlitine MgZn5 mass fractions $\left(\mathrm{Mg}\right.$ ) and the phase $\mathrm{MgZn}$ (or $\mathrm{Mg}_{7} \mathrm{Zn}_{3}$ ) with a zinc content of approximately $45 \%$ of mass fractions. The microstructure of the MgZn10 alloy is shown in Figure 2.

Table 2: Porosity of prepared materials

Tabela 2: Poroznost pripravljenih materialov

\begin{tabular}{|c|c|}
\hline Alloy & $\begin{array}{l}\text { Area fraction } \\
\text { pores }(\%)\end{array}$ \\
\hline MgZn5-2h & 8 \\
\hline MgZn5-4h & 8 \\
\hline MgZn5-24h & 10 \\
\hline MgZn10-2h & 6 \\
\hline MgZn10-4h & 6 \\
\hline MgAl5 & 2 \\
\hline MgAl3Zn1 & 5 \\
\hline MgY5 & 3 \\
\hline $\begin{array}{c}\text { MgZn5+10 \% of mass fractions of } \\
\left(\mathrm{NH}_{4}\right)_{2} \mathrm{CO}_{3}\end{array}$ & 30 \\
\hline $\begin{array}{c}\mathrm{MgZn5}+20 \% \text { of mass fractions of } \\
\left(\mathrm{NH}_{4}\right)_{2} \mathrm{CO}_{3}\end{array}$ & 42 \\
\hline $\begin{array}{c}\text { MgZn5+30\% of mass fractions of } \\
\left(\mathrm{NH}_{4}\right)_{2} \mathrm{CO}_{3}\end{array}$ & 48 \\
\hline $\begin{array}{l}\text { MgAl3Zn1+20\% of mass fractions of } \\
\qquad\left(\mathrm{NH}_{4}\right)_{2} \mathrm{CO}_{3}\end{array}$ & 18 \\
\hline
\end{tabular}

\section{2. $M g A l 5$}

The lowest porosity and pore size were determined in the alloy with $5 \%$ of mass fractions Al. All the pores had an equivalent diameter up to $200 \mu \mathrm{m}, 94 \%$ of them were smaller than $100 \mu \mathrm{m}$. The structure is formed by the $\mathrm{Mg}$-Al solid solution with an $\mathrm{Al}$ content of $5 \%$ of mass fractions. At the grain boundaries, the content increases, which may be caused by the presence of a eutectic phase consisting of a Mg-based solid solution and the $\mathrm{Mg}_{17} \mathrm{Al}_{12}$ phase. The microstructure of the alloy is shown in Figure 3.

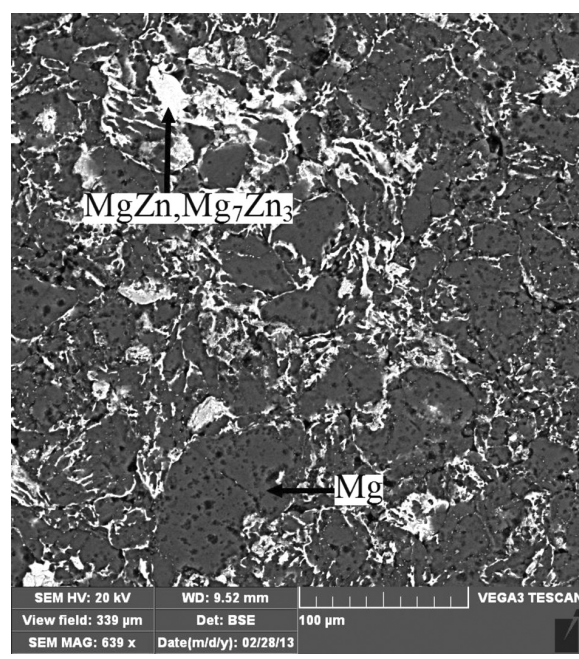

Figure 2: Microstructure of MgZn10 alloy

Slika 2: Mikrostruktura zlitine MgZn10 


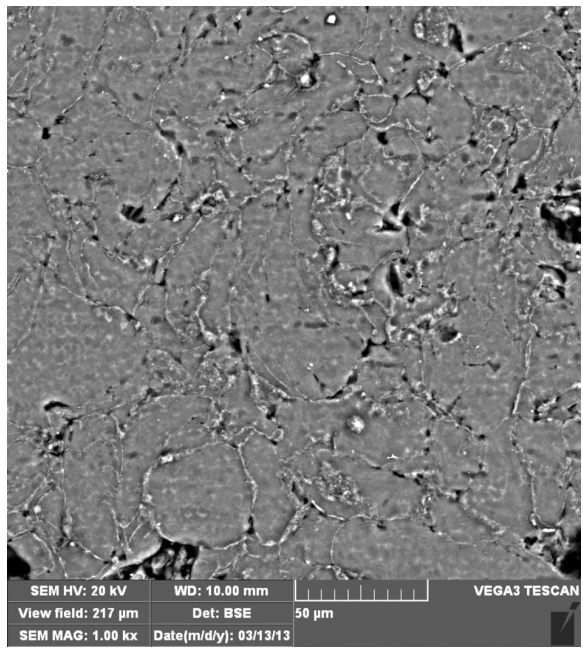

Figure 3: Microstructure of MgAl5 alloy

Slika 3: Mikrostruktura zlitine MgAl5

\subsection{MgAl3Zn1}

In the microstructure of the MgAl3Zn1 (AZ31) alloy, there are a large number of small pores, whose amount is similar to the alloy MgZn10. The sample consists of a solid solution of alloying elements in magnesium. The microstructure of the alloy is presented in Figure 4, the darker parts $\left(\mathrm{Mg}^{1}=96.5 \%\right.$ of mass fractions of $\mathrm{Mg}, 2.5$ $\%$ of mass fractions of $\mathrm{Al}, 1 \%$ of mass fractions of $\mathrm{Zn}$ ) have a lower content of $\mathrm{Al}$, in contrast to the lighter parts $\left(\mathrm{Mg}^{2}=95 \%\right.$ of mass fractions of $\mathrm{Mg}, 4 \%$ of mass fractions of $\mathrm{Al}, 1 \%$ of mass fractions of $\mathrm{Zn}$ ), zinc is dispersed homogeneously in the alloy.

\section{$3.4 \mathrm{MgY5}$}

The porosity of the alloy alloyed with yttrium is $3.1 \%$. From all the investigated samples, this alloy contains the largest amount of micropores, whose equivalent

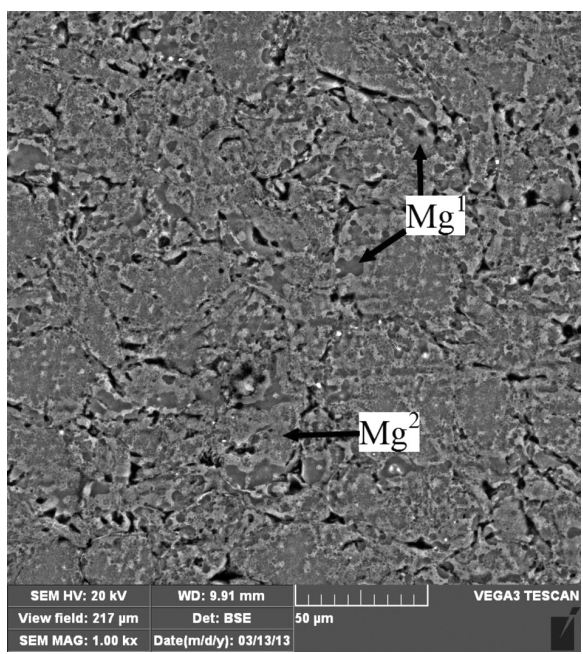

Figure 4: Microstructure of MgAl3Zn1 alloy

Slika 4: Mikrostruktura zlitine $\mathrm{MgAl} 3 \mathrm{Zn} 1$

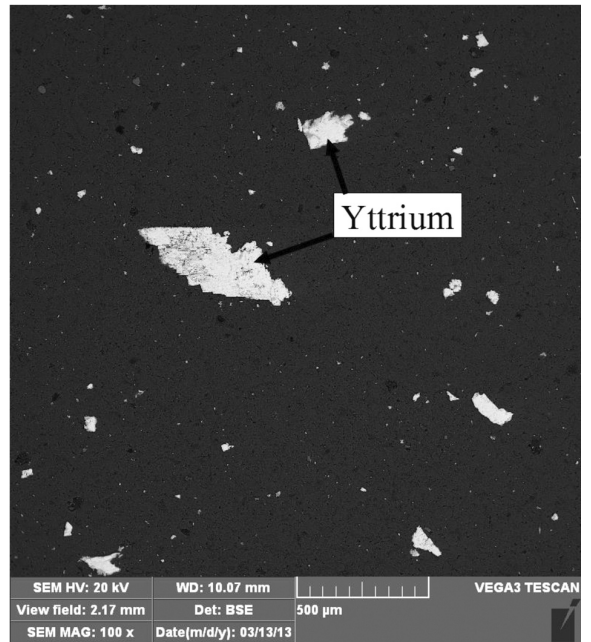

Figure 5: Microstructure of MgY5 alloy

Slika 5: Mikrostruktura zlitine MgY5

diameter is not greater than $10 \mu \mathrm{m}$. These small pores were probably caused by the low diffusion coefficient of yttrium in magnesium. During sintering the mutual diffusion was suppressed and in the structure there were maintained the rest of the pores after pressing. In the SEM micrograph (Figure 5) it is obvious that particles of yttrium are not dissolved in magnesium and the solid solution is not formed.

With the addition of a pore-forming agent, the alloys MgZn5 (10, 20 and $30 \%$ of mass fractions of ammonium carbonate) and MgAl3Zn1 (20\% of mass fractions of ammonium carbonate) were formed. With an increasing content of the pore-forming agent, the porosity of the alloy $\mathrm{MgZn} 5$ increased. In the structure of the alloy $\mathrm{MgAl} 3 \mathrm{Zn} 1+20 \%$ mass fractions of $\left(\mathrm{NH}_{4}\right)_{2} \mathrm{CO}_{3}$ there was a lower porosity than in the alloy $\mathrm{MgZn} 5$ with the same content of the pore-forming agent (Table 2). In Figure 6 there are pores with the required size (equiva-

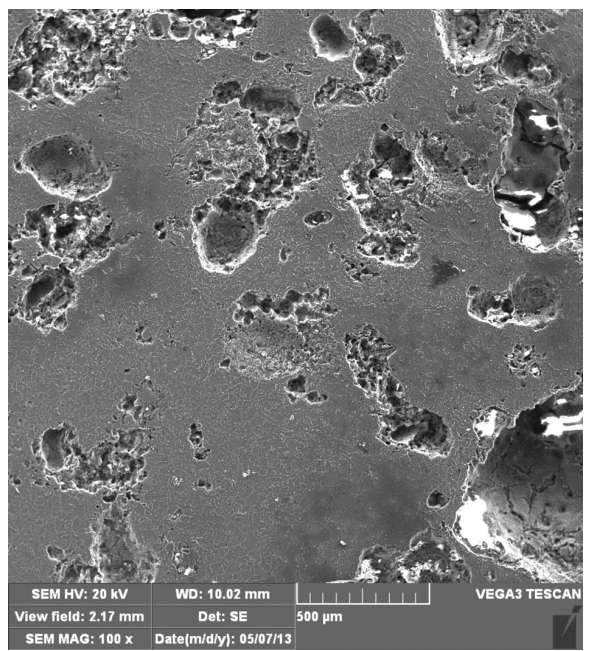

Figure 6: Microstructure of MgZn5 alloy with addition of $20 \%$ of mass fractions of $\left(\mathrm{NH}_{4}\right)_{2} \mathrm{CO}_{3}$

Slika 6: Mikrostruktura zlitine $\mathrm{MgZn} 5 \mathrm{z}$ dodatkom $20 \%$ masnega deleža $\left(\mathrm{NH}_{4}\right) \mathrm{CO}_{3}$ 


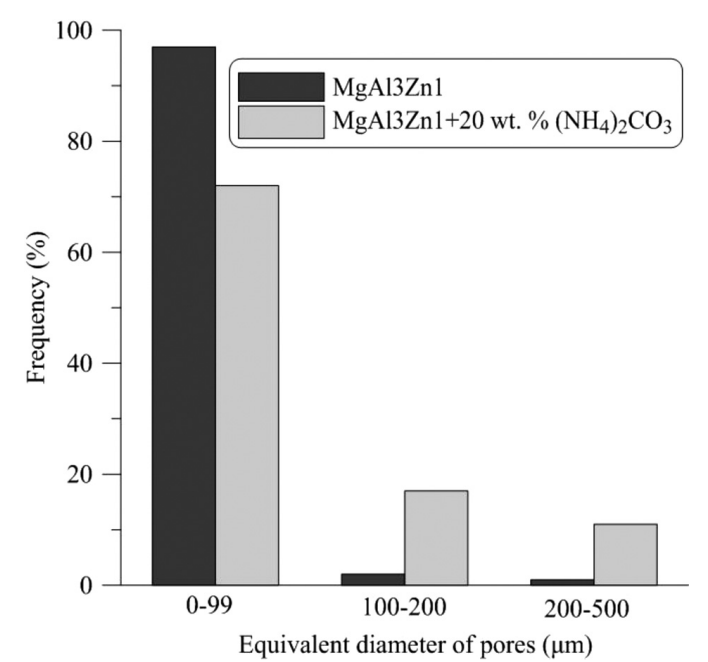

Figure 7: Alloy without pore-forming agent and with pore-forming agent

Slika 7: Zlitina brez sredstva za nastanek por in s sredstvom za nastanek por

lent diameter of more than $200-500 \mu \mathrm{m}$ ), which originated from the thermal decomposition of $\left(\mathrm{NH}_{4}\right)_{2} \mathrm{CO}_{3}$. In Figure 6 there are some cracks that may have been caused by the stress during the decomposition of the pore-forming agent.

In the samples without the pore-forming agent it was found that 85-95\% of the pores do not reach the required equivalent diameter of at least $100 \mu \mathrm{m}$ (in the alloy MgY5, as many as $99 \%$ of the pores). By adding the pore-forming agent the number of pores greater than $100 \mu \mathrm{m}$ increased. In Figure 7, the influence of the pore-forming agent on the size of the pores in the alloy $\mathrm{MgAl3Zn1}$ is presented. The most circular pores (69\%) are contained in the structure of the MgAl3Zn1 alloy. In

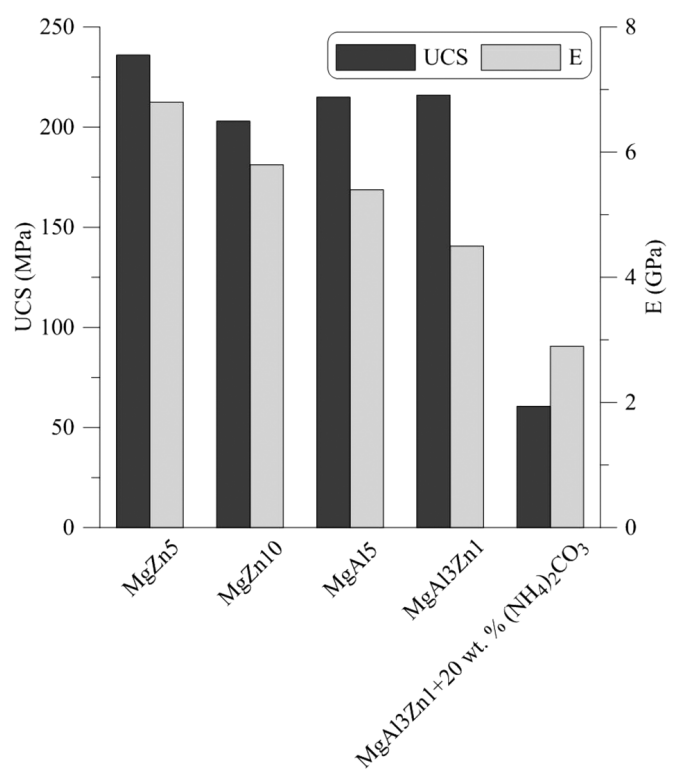

Figure 8: Compressive strength and modulus of elasticity of prepared samples

Figure 8: Tlačna trdnost in modul elastičnosti pripravljenih vzorcev the other alloys the amount of circular pores is 45-60\%. Adding the pore-forming agent into the alloy $\mathrm{MgAl} 3 \mathrm{Zn} 1$ decreased the quotient of the circular pores to $35 \%$.

The ultimate compressive strengths of the alloys are higher in comparison with the properties of natural bone (Table 1). The ultimate compressive strength is between $203 \mathrm{MPa}$ and $236 \mathrm{MPa}$. The modulus of elasticity is comparable with natural bone. A slightly lower modulus of elasticity was found in the case of the $\mathrm{MgAl} 3 \mathrm{Zn} 1$ alloy, in contrast with the other alloys. Increased porosity and the presence of large pores cause a significant decrease in the mechanical properties. The results of the compression test (UCS, E) are shown in Figure 8.

\section{CONCLUSION}

Magnesium alloys prepared by powder metallurgy without a pore-forming agent have an adequate modulus of elasticity and a higher ultimate compressive strength than natural bones. In the microstructure of magnesium alloys alloyed with zinc and aluminium, the solid solution dominates. An exception is the microstructure of the alloy $\mathrm{MgY5}$, where the particles of yttrium did not dissolve in magnesium. The porosity of the samples without the pore-forming agent is up to $10 \%$ of the volume fractions. Approximately $90 \%$ of pores have an equivalent diameter of less than $100 \mu \mathrm{m}$. The addition of the pore-forming agent $-\left(\mathrm{NH}_{4}\right)_{2} \mathrm{CO}_{3}-$ to the alloys $\operatorname{MgZn} 5$ and $\mathrm{MgAl} 3 \mathrm{Zn} 1$, increases the quantity of pores with an equivalent diameter of $200 \mu \mathrm{m}$ and an area fraction of pores to $18-48 \%$ of the volume fractions. The ultimate compressive strength reached 203-236 $\mathrm{MPa}$. With an increasing porosity after adding the $\left(\mathrm{NH}_{4}\right)_{2} \mathrm{CO}_{3}$ it decreases to $61 \mathrm{MPa}$.

\section{Acknowledgement}

This research was financially supported by Czech Science Foundation, project No. P108/12/G043.

\section{REFERENCES}

${ }^{1}$ B. L. Mordike, T. Ebert, Magnesium: Properties - applications potential, Materials Science and Engineering A, 302 (2001) 1, 37-45, doi:10.1016/S0921-5093(00)01351-4

${ }^{2}$ D. Vojtěch, V. Knotek, Magnesium alloys for hydrogen storage, Mater. Tehnol., 46 (2012) 3, 247-250

${ }^{3}$ G. Klačnik, M. Zdovc, U. Kovšca, B. Praček, J. Kovač, J. Rozman, Osseointegration and rejection of a titanium screw, Mater. Tehnol., 44 (2010) 5, 261-264

${ }^{4}$ D. Vojtěch, V. Knotek, J. Čapek, J. Kubásek, Hořčík - kov pro medicínu i pro skladování vodíku, Chemicke listy, 105 (2011) 9, 678-683

${ }^{5}$ N. Li, Y. Zheng, Novel Magnesium Alloys Developed for Biomedical Application: A Review, Journal of Materials Science \& Technology, 29 (2013) 6, 489-502, doi:10.1016/j.jmst.2013.02.005

${ }^{6}$ J. Kubásek, I. Pospíšilová, D. Vojtěch, E. Jablonská, T. Ruml, Structural, mechanical and cytotoxicity characterization of as-cast biodegradable $\mathrm{Zn}-\mathrm{xMg}(\mathrm{x}=0.8-8.3 \%$ ) alloys, Mater. Tehnol., 48 (2014) 5, 623-629 


\section{P. SALVETR et al.: POROUS MAGNESIUM ALLOYS PREPARED BY POWDER METALLURGY}

${ }^{7}$ J. Čapek, D. Vojtěch, Effect of sintering conditions on the microstructural and mechanical characteristics of porous magnesium materials prepared by powder metallurgy, Materials Science and Engineering C, 35 (2014), 21-28, doi:10.1016/j.msec.2013.10.014

${ }^{8}$ H. Zhuang, Y. Han, A. Feng, Preparation, mechanical properties and in vitro biodegradation of porous magnesium scaffolds, Materials Science and Engineering C, 28 (2008) 8, 1462-1466, doi:10.1016/ j.msec.2008.04.001

${ }^{9}$ C. E. Wen, Y. Yamada, K. Shimojima, Y. Chino, H. Hosokawa, M Mabuchi, Compressibility of porous magnesium foam: dependency on porosity and pore size, Materials Letters, 58 (2004) 3-4, 357-360, doi:10.1016/S0167-577X(03)00500-7

${ }^{10}$ C. E. Wen, M. Mabuchi, Y. Yamada, K. Shimojima, Y. Chino, T. Asahina, Processing of biocompatible porous $\mathrm{Ti}$ and $\mathrm{Mg}$, Scripta Materialia, 45 (2001) 10, 1147-1153, doi:10.1016/S1359-6462(01) 01132-0

${ }^{11}$ M. Socjusz-Podosek, L. Lityńska, Effect of yttrium on structure and mechanical properties of $\mathrm{Mg}$ alloys, Materials Chemistry and Physics, 80 (2003) 2, 472-475, doi:10.1016/S0254-0584(02)00549-7 ${ }^{12}$ F. Feyerabend, J. Fischer, J. Holtz, F. Witte, R. Willumeit, H. Drücker, C. Vogt, N. Hort, Evaluation of short-term effects of rare earth and other elements used in magnesium alloys on primary cells and cell lines, Acta Biomaterialia, 6 (2010) 5, 1834-1842, doi:10.1016/j.actbio.2009.09.024
${ }^{13}$ K. U. Kainer, P. Bala Srinivasan, C. Blawert, W. Dietzel, 3.09 Corrosion of Magnesium and its Alloys, In Shreir's Corrosion, Elsevier, Oxford 2010, 2011-2041, doi:10.1016/B978-0444527875.00096-2

${ }^{14}$ F. Witte, N. Hort, C. Vogt, S. Cohen, K. U. Kainer, R. Willumeit, F. Feyerabend, Degradable biomaterials based on magnesium corrosion, Current Opinion in Solid State and Materials Science, 12 (2008) 5-6, 63-72, doi:10.1016/j.cossms.2009.04.001

${ }^{15}$ V. Karageorgiou, D. Kaplan, Porosity of 3D biomaterial scaffolds and osteogenesis, Biomaterials, 26 (2005) 27, 5474-5491, doi:10.1016/j.biomaterials.2005.02.002

${ }^{16}$ J. Čapek, D. Vojtěch, Properties of porous magnesium prepared by powder metallurgy, Materials Science and Engineering C, 33 (2013) 1, 564-569, doi:10.1016/j.msec.2012.10.002

${ }^{17}$ N. T. Kirkland, I. Kolbeinsson, T. Woodfield, G. J. Dias, M. P. Staiger, Synthesis and properties of topologically ordered porous magnesium, Materials Science and Engineering B, 176 (2011) 20, 1666-1672, doi:10.1016/j.mseb.2011.04.006 